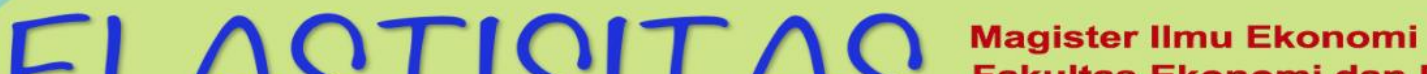 Fakultas Ekonomi dan Bisnis Universitas Mataram

\section{Guncangan Indikator Makro Terhadap \\ Transmisi Kebijakan Moneter Pada Jalur Nilai Tukar}

Taufiq Chaidir ${ }^{1^{*}}$ dan Gusti Ayu Arini ${ }^{1}$

${ }^{1}$ Fakultas Ekonomi dan Bisnis, Universitas Mataram

*email korespondensi : taufiqch@unram.ac.id

Info Artikel

Kata Kunci:

guncangan,

transmisi kebijakan

moneter,

volatilitas,

nilai tukar,

kelambanan waktu, vector error corection model
ABSTRAK

Dinamika perubahan indikator moneter dalam mekanisme transmisi kebijakan moneter, dipedomani sebagai instrumen pengendalian sasaran akhir stabilitas harga dan nilai tukar. Penelitian ini bertujuan untuk menguji kelambanan waktu (time lag) yang dibutuhkan oleh indikator inflasi, jumlah uang beredar (JUB), suku bunga sertifikat Bank Indonesia (rSBI), dan nilai tukar (kurs), sekaligus untuk membuktikan guncangan (shock) dan respon indikator-indikator tersebut dalam transmisi kebijakan moneter padajalur nilai tukar di Indonesia. Pendekatan penelitian yang digunakan adalah pendekatan kuantitatif (post positivisme). Adapun sumber data adalah data sekunder time series dalam bentuk data bulanan selama periode 2008.1-2016.12. Model analisis menggunakan Vector Autoregresive dan Vector Error Corection Model (VAR-VECM). Hasil pengujian perilaku data menunjukkan bahwa seluruh variabel stasioner dan berkointegrasi pada derajat 1. Mekanisme transmisi kebijakan moneter melalui jalur nilai tukar membutuhkan time lag atau kecepatan sekitar 6 bulan hingga terwujudnya sasaran akhir kebijakan moneter (inflasi). Guncangan (shock) indikator makro pada jalur nilai tukar terhadap perubahan suku bunga SBI relatif lemah, sedangkan indikator nilai tukar (kurs), hanya mampu menjelaskan variasi inflasi sebesar 3,15 persen, lebih kecil dibandingkan dengan porsi yang dapat dijelaskan oleh indikator jumlah uang beredar (JUB). Bank 


\section{Elastisitas - Jurnal Ekonomi Pembangunan}

Vol. 1 No. 1, (2019), 54 - 65

Indonesia sebagai otoritas moneter tertinggi, harus dapat mendeteksi volatilitas nilai tukar agar inflasi dapat dikendalikan pada tingkat yang ditargetkan dan stabil. 


\section{Elastisitas - Jurnal Ekonomi Pembangunan \\ Vol. 1 No. 1, (2019), 54 - 65}

\section{PENDAHULUAN}

Kebijakan moneter adalah semua upaya atau tindakan Bank Sentral dalam mempengaruhi perkembangan variabel moneter seperti uang beredar, suku bunga, kredit dan nilai tukar guna mencapai tujuan ekonomi tertentu. Sebagai bagian dari kebijakan ekonomi makro, maka tujuan kebijakan moneter adalah untuk mencapai pertumbuhan ekonomi, penyediaan lapangan kerja, stabilitas harga dan keseimbangan neraca pembayaran. Keempat sasaran tersebut merupakan tujuan akhir kebijakan moneter.

Proses yang menggambarkan perubahan kebijakan moneter karena berubahnya instrumen moneter melalui suatu mekanisme, dalam teori ekonomi dan kebijakan moneter dinamakan sebagai mekanisme transmisi kebijakan moneter. Transmisi kebijakan moneter merupakan jalur-jalur (channels) yang dilalui oleh suatu kebijakan moneter hingga dapat mempengaruhi tujuan akhir kebijakan moneter. Mekanisme transmisi kebijakan moneter yang standar dimulai dari tindakan bank sentral mendeteksi perubahan pada instrumen kebijakan moneter. Tindakan ini kemudian mempengaruhi sasaran operasional (operational target) dan sasaran antara (intermediate target) yang pada akhirnya mempengaruhi tujuan akhir kebijakan moneter (final target) (Warjiyo, 2004).

Mengingat kompleksitas dalam teori ekonomi moneter, mekanisme transmisi kebijakan moneter sering disebut "black box" (Mishkin:1995), karena transmisi dimaksud banyak dipengaruhi oleh tiga faktor, yaitu: perubahan perilaku bank sentral, perbankan, dan para pelaku ekonomi dalam berbagai aktivitas ekonomi dan keuangannya; lamanya tenggat waktu (time lag) sejak tindakan otoritas moneter sampai sasaran akhir tercapai, serta terjadinya perubahan pada jalur-jalur transmisi moneter itu sendiri sesuai dengan perkembangan ekonomi dan keuangan di negara yang bersangkutan.
Strategi kebijakan moneter yang kredibel sangat bergantung pada jalur mekanisme transmisi kebijakan moneter. Selanjutnya jalur mekanisme transmisi kebijakan moneter akan mempengaruhi stabilitas sistem keuangan, namun kenyataannya terdapat indikasi efek dari transmisi masih lemah (Bhattacharya, Patnaik dan Shah, 2011). Seperti diketahui bahwa mekanisme transmisi kebijakan moneter dibuat melalaui enam jalur, yakni jalur jumlah uang beredar, suku bunga, nilai tukar, kredit, harga aset, dan ekspektasi (Mohan, 2006). Secara teoritis, jalur yang paling dominan dan signifikan adalah jalur suku bunga, karena itu mempengaruhi pasar keuangan melalui jalur lainnya. Namun, secara empiris di negara-negara berkembang, jika kondisi dimana pasar keuangan yang belum berkembang dan sistem perbankan yang tidak efisien, terbukti bahwa mekanisme transmisi melalui suku bunga masih lemah (Moreno, 2008). Fakta lain diungkapkan bahwa masih relatif kurangnya dana pinjaman sehingga berdampak pada permintaan agregat dan lemahnya transmisi pada jalur kredit, yang pada akhirnya menciptakan efek pada tingkat bunga (Bernanke dan Gertler, 1995, Mohan, 2006). Pendapat (Adolf Son, 2001, Bjornland, 2005) mengungkapkan bahwa pada jalur nilai tukar diakibatkan adanya efek yang signifikan oleh sinyal dan guncangan transmisi pada instrumen moneter.

Sejak Agustus 1997 di Indonesia diberlakukannya sistem nilai tukar mengambang penuh/ bebas (freely floating system), dimana posisi nilai tukar rupiah terhadap mata uang asing (khususnya US dolar) ditentukan oleh mekanisme pasar. Sejak masa itu naik turunnya nilai tukar (fluktuasi) ditentukan oleh kekuatan pasar. Gambaran pergerakan nilai rupiah seperti tertera dalam grafik berikut. 


\section{Elastisitas - Jurnal Ekonomi Pembangunan \\ Vol. 1 No. 1, (2019), 54 - 65}

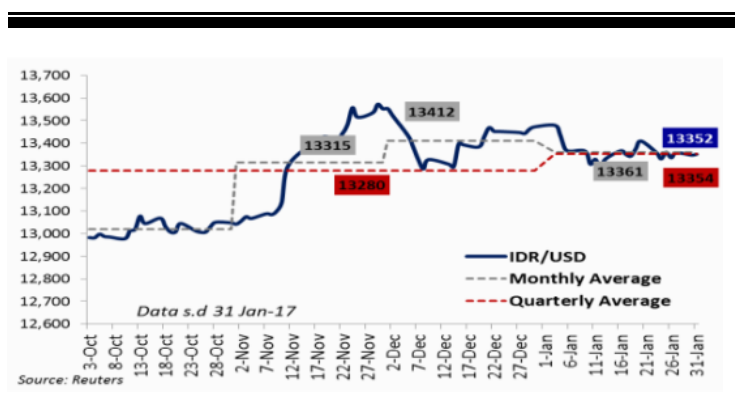

Tekanan terhadap rupiah pada triwulan ke-empat tahun 2016 secara point to point melemah (terdepresiasi) sebesar 3,13 persen menjadi Rp. 13.473 per US dolar. Kondisi tersebut diakibatkan oleh bebera hal, antara lain adanya guncangan terhadap kondisi ekonomi globar, perubahan terhadap tingkat suku bunga the FED, kenaikan terhadap permintaan valas, baik oleh perseorangan, perusahaan, maupun oleh pemerintah dalam rangka pembayaran hutang luar negeri pada akhir tahun. Tekanan terhadap nilai tukar diakibatkan juga oleh guncangan interdependensi indikator moneter jumlah uang beredar, suku bunga, nilai tukar, dan inflasi. Untuk itu penguatan kebijakan adalah dalam rangka menurunkan tekanan inflasi sehingga dapat segera kembali kepada lintasan sasarannya dan menurunkan defisit transaksi berjalan ke tingkat yang lebih sehat. Sebagai langkah antisipatif (preemptive) merespons naiknya tekanan inflasi, menaikkan suku bunga acuan, memperkuat operasi moneter, memperdalam pasar keuangan, mengelola lalu lintas devisa, dan menjaga stabilitas nilai tukar rupiah agar sesuai dengan kondisi fundamentalnya (BI, 2013).

Di negara-negara maju sudah banyak studi yang membahasa indikator nilai tukar sebagai instrumen yang menentukan mekanisme transmisi moneter (Coibion, 2012, Bernanke dan Blinder,1992, Eichenbaum dan Evans, 1995, Taylor, 1995, Sims dan Jha, 2006), sedangkan di negara-negara berkembang terutama di Indonesia relatif sedikit studi yang membahas hal tersebut. Terutama masih relatif sedikitnya studi yang meneliti dan pembuktian panjangnya waktu (time lag). Seperti diketahui bahwa mekanisme transmisi kebijakan moneter ini bekerja memerlukan waktu (time lag). Time lag masing-masing jalur bisa berbeda dengan yang lain. Jalur nilai tukar biasanya bekerja lebih cepat karena dampak perubahan suku bunga kepada nilai tukar bekerja sangat cepat. Kondisi sektor keuangan dan perbankan juga sangat berpengaruh pada kecepatan transmisi kebijakan moneter. Apabila perbankan melihat risiko perekonomian cukup tinggi, respon perbankan terhadap penurunan suku bunga $\mathrm{BI}$ rate biasanya sangat lambat.

Penelitian ini bertujuan untuk membuktikan berapa lama waktu (time lag) guncangan oleh indikator-indikator moneter pada transmisi kebijakan moneter melalui jalur nilai tukar. Tujuan selanjutnya dari penelitian ini didasari atas beberapa pertimbangan empiris, pertama : sebagian besar studi sebelumnya secara langsung menggunakan kerangka vector autoregresive (VAR), tanpa memasukkan kesalahan kointegrasi. Karena variabelvariabel makroekonomi biasanya tidak stasioner dan tidak berointegrasi pada level. Olah karena itu harus menjadi pertimbangan untuk menggunakan vector error corection model (VECM). Kedua, sebagian besar studi tentang masalah efek kebijakan moneter di India, diterapkan berdasarkan pertimbangan ukuran sampel. (Bhattacharya dan Ray, 2007) atau variabel kebijakan tunggal dalam kerangka multivariat (Bhattacharya, Patnaik dan Shah, 2011) atau mereka memilih menggunakan instrumen kebijakan secara terpisah untuk menguji efek dari guncangan kebijakan (Bhattacharya dan Sensarma, 2008).

Satu kelemahan dalam pendekatan VAR yang disorot oleh (Bernanke, Boivin, and Eliasz, 2005), adalah bahwa pendekatan VAR standar hanya membahas dampak dari perubahan tak terduga dalam kebijakan moneter, yang lebih penting bukan efek dari bagian sistematis kebijakan moneter atau pilihan aturan kebijakan moneter. Sebagian besar kritik ini fokus kepada terbatasnya jumlah variabel yang digunakan dalam estimasi. Untuk 


\section{Elastisitas - Jurnal Ekonomi Pembangunan \\ Vol. 1 No. 1, (2019), 54 - 65}

mengatasi kelemahan ini (Bernanke, Boivin, \& Eliasz, 2005) menyarankan menggunakan VAR faktor (FVAR) dengan jumlah data longitudinal yang relatif panjang.

Bagian pertama dari paper ini seperti yang telah dijelaskan sebelumnya, Bagian ke-2 membahas literatur review dan kesenjangan penelitian (research gap), Bagian ke- 3 membahas model empiris, dan Bagian ke-4 membahas hasil pembuktian atau pengujian empiris, serta Bagian ke-5 simpulan dan saran kebijakan.

\section{LITERATUR REVIEW}

Saeed et al (2012) studi empiris yang berjudul "An Econometric Analysis of Determinants of Exchange Rate In Pakistan" dengan menggunakan pendekatan model dinamik Autoregresive Distributed Lag (ARDL), kointegrasi dan ECM, simpulannya mendukung peran faktor ekonomi dan non ekonomi dalam penentuan nilai tukar di Pakistan. Lebih lanjut diungkapkan bahwa harga relatif surat berharga (saham) dan hutang luar negeri berpengaruh positif dan signifikan terhadap nilai tukar, cadangan devisa relatif berpengaruh negatif dan signifikan terhadap nilai tukar Pakistan. Ketidakstabilan politik berpengaruh negatif terhadap nilai tukar. Variabel tingkat bunga relatif jangka pendek dan PDB riil relatif tidak signifikan terkait dengan penentuan nilai tukar.

Moura (2010) menguji model ekonomi Chile, Meksiko, Peru, Brasil dan Kolombia, dengan menggabungkan konsep nilai tukar dan kebijakan moneter. Peramalan hasil estimasi menggunakan fungsi reaksi dari Taylor Rule. Temuan empiris diungkapkan bahwa suku bunga merespon positif terhadap kesenjangan GDP, kenaikan tingkat harga relatif dan target inflasi. Dan disimpulkan bahwa penelitian ini didukung dengan menggunakan pendekatan moneter, ketersediaan data, teknik ekonometrik, dan ketepatan dalam spesifikasi model. Terlepas dari dukungan tersebut, hasil temuan tetap saja tidak bisa diklaim secara superioritas terhadap pendekatan lain guna menjelaskan perilaku nilai tukar.

Hsieh (2009) telah mempelajari perilaku Rupiah Indonesia per unit US Dollar. Menggunakan model MundellFleming, hasil penelitian diungkapkan bahwa nilai tukar dipengaruhi oleh jumlah uang beredar secara signifikan, tingkat bunga relatif dalam negeri yang lebih tinggi, atau tingkat harga relatif dianggap sebagai penyebab melemahnya (depresiasi) terhadap nilai tukar Rupiah. Semakin tinggi rasio pengeluaran pemerintah terhadap PDB atau kenaikan harga saham, akan menyebabkan menguatnya (apresiasi) terhadap nilai tukar rupiah per US dolar.

Wilson (2009) meneliti nilai tukar rata-rata tertimbang efektif US dollar berdasarkan mitra dagang dengan Amerika Serikat. Jumlah uang beredar secara positif berkaitan dengan nilai tukar, dan peningkatan jumlah uang beredar menyebabkan penurunan nilai tukar efektif. Koefisien estimasi tingkat bunga, pengeluaran pemerintah dan defisit terhadap PDB secara negatif berhubungan dengan nilai tukar efektif

Karim et al (2007) menggunakan data kuartalan terhadap variabel makroekonomi di Selandia Baru dan mitra dagangnya (Australia, Jepang dan Amerika Serikat). Hasil temuannya mengungkapkan banhwa guncangan kebijakan moneter berdampak terhadap nilai tukar nominal dan efektif Selandia Baru. Estimasi empiris dari penelitian ini mengungkapkan bahwa implementasi kebijakan moneter yang ketat menyebabkan menguatnya (apresiasi) nilai tukar nominal dan nilai tukar efektif.

Chin et al (2007) menguji versi alternatif model moneter untuk nilai tukar Ringgit Malaysia per unit US Dollar, menggunakan pendekatan kointegrasi Johansen, serta mengacu kepada studi Dornbusch (1978) bahwa jumlah uang beredar dan pendapatan agregat adalah konsisten, namun variabel tingkat bunga memiliki tanda positif. 


\section{Elastisitas - Jurnal Ekonomi Pembangunan \\ Vol. 1 No. 1, (2019), 54 - 65}

Penelitian serupa juga dilakukan oleh Maina Vincent Gitonga (2006). Penelitian ini bertujuan untuk meneliti dampak dari mekanisme transmisi moneter pada jalur suku bunga di Kenya, dengan menggunakan data kuartalan selama periode 2005-2013. Alat analisis yang digunakan adalah menggunakan model VAR, untuk menguji dampak relatif dari variabel yang berbeda, yakni suku bunga repo, NEER, M3, CPI, GDP, dan tabungan. Hasil analisis menemukan dua hal yang menarik, pertama : semua variabel stasioner pada level 1. Kedua : kecuali jumlah uang dalam arti yang luas (M3), terdapat pengaruh yang signifikan dan guncangan yang kuat terhadap gross domestic product (GDP) dan Consumers Price Index (CPI) pada jalur suku bunga, meskipun berpengaruh signifikan namun guncangannya lemah terhadap NEER.

Penelitian yang dilakukan oleh Tomas Havranek and Marek Rusnak (2005) terkait dengan lag transmisi kebijakan moneter, menggunakan meta analisis. Transmisi kebijakan moneter dalam perekonomian pada umumnya diduga memiliki lag dalam kurun waktu yang lama, rata-rata lag transmisi adalah selama dua puluh sembilan bulan, dan guncangan kebijakan terhadap harga rata-rata mencapai 0,9 persen. Sebaliknya lag transmisi lebih lama terjadi di negaranegara maju yakni selama 25-50 bulan, namun jika kondisi ekonomi setelah terjadinya masa transisi, jumla lag adalah selama 10-20 bulan. Hasil temuan selanjutnya diungkapkan bahwa faktor yang paling efektif dalam menjelaskan heterogenitas perkembangan sektor moneter adalah sebagai akibat lambannya transmisi kebijakan moneter.

Hyder dan Mehboob (2005) mengestimasi keseimbangan nilai tukar riil efektif (EREER) terhadap Rupee Pakistan. Berdasarkan identifikasi terhadap derajat keterbukaan ekonomi, peningkatan pengeluaran pemerintah dan keseimbangan neraca modal, adalah indikator-indikator yang mengakibatkan melemahnya (depresiasi) nilai tukar riil efektif.

Karfakis (2003) menguji model nilai tukar mata uang Rumania terhadap US Dollar dan menyimpulkan bahwa jumlah uang beredar adalah positif berkaitan dengan nilai tukar. Kenaikan jumlah uang beredar adalah sumber dari melemahnya (depresiasi) nilai tukar domestik. Pendapatan riil adalah berpengaruh negatif terhadap nilai tukar, sedangkan inflasi berpengaruh positif berkaitan dengan nilai tukar Rumania terhadap US Dolar.

\section{METODE PENELITIAN}

Pendekatan yang digunakan dalam penelitian ini adalah pendekatan kuantitatif (post positivisme). Adapun Jenis data yang digunakan dalam penelitian adalah data sekunder berupa data time series, dalam bentuk data bulanan yakni selama periode 2008.1 sampai dengan peride 2016.12. Variabel utama dalam penelitian ini adalah inflasi, suku bunga sertifikat Bank Indonesia (rSBI), jumlah uang beredar (JUB), dan nilai tukar rupiah terhadap US dolar (Kurs).

Variabel utama tersebut secara operasional didefinisikan sebagai berikut: (1) Inflasi sebagai ukuran yang menggambarkan perubahan tingkat harga umum terhadap harga barang-barang dan jasa. Perubahan tingkat harga umum terhadap barang-barang dan jasa menggunakan pendekatan indek harga konsumen (IHK), dalam satuan prosen. (2) rSBI sebagai ukuran yang menggambarkan suku bunga sertifikan Bank Indonesia, dinyatakan dalam persen. (3) Jumlah uang beredar, sebagai ukuran terhadap likuiditas perekonomian dalam bentuk jumlah uang yang diedarkan dalam arti yang luas, dalam satuan milyar rupiah. (4) Nilai Tukar (kurs valuta asing) suatu ukuran yang menggambarkan perubahan nilai tukar mata uang domestik terhadap mata uang asing, atau perubahan nilai tukar rupiah terhadap dolar AS yang dihitung 


\section{Elastisitas - Jurnal Ekonomi Pembangunan \\ Vol. 1 No. 1, (2019), 54 - 65}

berdasarkan kurs tengah. Nilainya dalam satuan rupiah per US dolar (IDR/USD).

Model analisis yang digunakan adalah model Vector Autoregresive (VAR). Analisis VAR mula - mula dikembangkan oleh Christopher Sims pada awal tahun 1980-an sebagai kritiknya pada modelmodel ekonometrik simultan yang komplek (Enders, 1995; Gujarati, 1995). Para pengkritik metode analisis VAR adalah Cooley dan Leroy (1985) dan Bernake (1986). Inti kritiknya adalah interpretasi hasil analisis VAR tidak bisa dilepaskan dari suatu model struktural ekonomi makro, untuk itu perlu diintroduksikan batasanbatasan (restriksi) dalam modelnya. Adapun skema tahapan model VAR dijelaskan dalam gambar berikut.

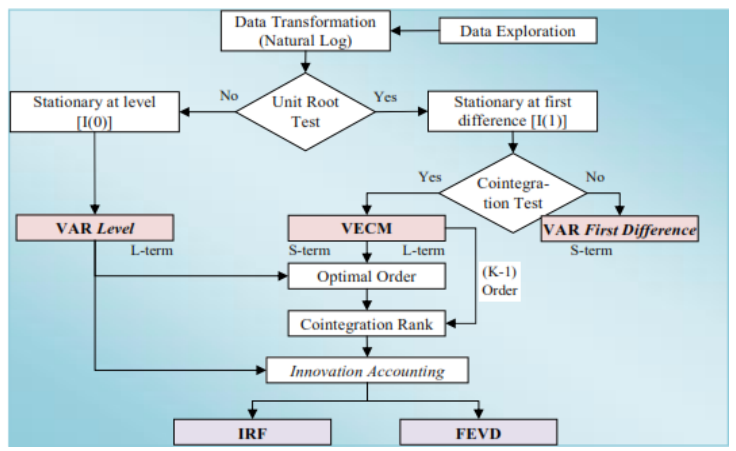

Sumber : Ascarya, et al (2008)

Bentuk umum model VAR adalah untuk menguji hubungan antara inflasi, rSBI, JUB, dan, nilai tukar (kurs). Pada tahap awal kita mengasumsikan bahwa VAR tersebut mengandung panjang lag 1 sampai i, sehingga persamaan tersebut dapat diformulasikan sebagai berikut.

Inflasit $=\mathrm{a} 1+\alpha$ inflasit $-1+\alpha 2$ rSBIt $-1+$ $\alpha 3 J \mathrm{UB}_{\mathrm{t}-1}+\alpha 4 \mathrm{Kurst}_{\mathrm{t}-1}+\beta 1$ Inflasit$\mathrm{i}+\beta 2 \mathrm{rSBI}_{\mathrm{t}-\mathrm{i}}+\beta 3 \mathrm{JUB}_{\mathrm{t}-\mathrm{i}}+\beta 4 \mathrm{kurs}_{\mathrm{i}}$ $+\mathrm{e} 1 \mathrm{t}$

rSBIt $=\mathrm{a} 2+\alpha 1$ Inflasi $_{\mathrm{t}-1}+\alpha 2$ rSBI $_{\mathrm{t}-1}+$ $\alpha 3 \mathrm{JUB}_{\mathrm{t}-1}+\alpha 4$ kurst $-1+\beta 1$ inflasit-i $_{\text {in }}$ $+\beta 2$ rSBIt $_{\mathrm{i}}+\beta 3 \mathrm{JUB}_{\mathrm{t}-\mathrm{i}}+\beta 4$ kurst $-\mathrm{i}^{-}$ $+\mathrm{e} 2 \mathrm{t}$

$\mathrm{JUBt}=\mathrm{a} 3+\alpha 1$ inflasi $_{\mathrm{t}-1}+\alpha 2$ rSBI $_{\mathrm{t}-1}+$ $\alpha 3 \mathrm{JUB}_{\mathrm{t}-1}+\alpha 4$ kurst $-1+\beta 1$ inflasit-i $+\beta 2$ rSBI $_{t-i}+\beta 3$ JUB $_{t-i}+\beta 4$ kurst $-\mathrm{i}^{-}$ $+\mathrm{e} 3 \mathrm{t}$
Kurst $=\mathrm{a} 4+\alpha$ inflasit-1 $+\alpha 2$ rSBIt-1 + $\alpha 3 \mathrm{JUB}_{\mathrm{t}-1}+\alpha 4$ kurst $-1+\beta 1$ inflasit-i $_{\text {t }}$ $+\beta 2 \mathrm{rSBI}_{\mathrm{t}-\mathrm{i}}+\beta 3 \mathrm{JUB}_{\mathrm{t}-\mathrm{i}}+\beta 4$ kurst $-\mathrm{i}^{-}$ $+\mathrm{e} 4 \mathrm{t}$

Dimana : ai, $\alpha \mathrm{i}$, dan $\beta \mathrm{i}$ : parameter yang akan di estimasi; $\mathrm{t}-\mathrm{i}=$ lag ke $\mathrm{i}$

Persamaan di atas mencerminkan bahwa setiap variabel dalam metode model VAR tergantung pada struktur lag yang sama yang digunakan pada setiap variabel dalam semua persamaan, karena tidak ada ristriksi maka semua parameter $\alpha$ dan $\beta$ adalah nilainya tidak sama dengan nol.

Tahapan pengujian selanjutnya adalah.

a. Pengujian uji akar-akar unit (Unit Roots Test)

b. Penentuan Lag Optimal

Untuk mengetahui jumlah lag optimal yang digunakan dalam uji stasioneritas, berikut adalah kriteria yang digunakan.

Akaike Information Criterion (AIC) :

$-2\left(\frac{1}{T}\right)+2(k+T)$

Schwarz Information Criterion (SIC) :

$-2\left(\frac{1}{T}\right)+k \frac{\log (T)}{T}$

Hannan-Quinn Information Criterion (HQ): $-2\left(\frac{1}{T}\right)+2 k \log \left(\frac{\log (T)}{T}\right)$

dimana

1 = Nilai fungsi log likelihood yang sama jumlahnya dengan $-\frac{T}{2}(1+$ $\left.\log (2 \pi)+\log \left[\frac{\varepsilon^{\prime \prime} \varepsilon^{\prime}}{T}\right]\right) ; \varepsilon^{\prime \prime} \varepsilon^{\prime}$ merupakan sum of squared residual

$\mathrm{T} \quad=$ jumlah obeservasi

$\mathrm{k} \quad=$ parameter yang diestimasi

c. Pengujian kointegrasi menggunakan metode Johansen's Multivariate Cointegration Test.

\section{d. VECM}

Model VECM digunakan jika dalam persamaan terdapat kointegrasi antar variabel atau rank kointegrasi (r) lebih dari nol, jika data yang digunakan tidak stasioner namun terkointegrasi (Juanda dan Junaidi, 2012). 
Adapun spesifikasi model VECM secara umum adalah sebagai berikut. (Firdaus, 2017, 172).

$$
\begin{aligned}
& \Delta \mathrm{yt}=\propto 0 \mathrm{x}+\beta \mathrm{xt}+ \\
& \prod \mathrm{xy}_{\mathrm{t}-1} \sum_{\mathrm{i}=1}^{\mathrm{k}-1} \Gamma \mathrm{ix} \Delta \mathrm{y}_{\mathrm{t}-1}+e t
\end{aligned}
$$

Dimana :

yt : vektor variabel Inflasi, rSBI, JUB, dan kurs

$\propto 0 \mathrm{x}:$ vektor intercept

$\beta x t \quad$ : vektor koefisien regresi

$\mathrm{t}$ : time trend

$\prod \mathrm{x}$ : kointegrasi jangka panjang

$\mathrm{Y}_{\mathrm{t}-1}$ : variabel in-level

Гix : matriks koefisien regresi

k-1 : ordo VECM dari VAR

et : error term

e. Impulse Response Function (IRF)

f. Forecast Error Variance

Decompisitions (FEVD), atau biasa disebut dengan Variance Decomposition.

\section{HASIL DAN PEMBAHASAN}

\section{Hasil Uji Stasioneritas Data}

Uji stasioneritas data dilakukan pada setiap variabel yang digunakan dalam model. Pengujian stasioneritas digunakan untuk menguji stasioneritas data agar terhindar dari spurious regression atau regresi palsu, sehingga apabila masing-masing variabel bersifat stasioner maka koefisien dalam model akan menjadi valid. Pembetukan VECM dapat digunakan apabila variabel endogen dalam model tidak stasioner pada tingkat level atau 1(0). Dalam menentukan stasioneritas variabel, maka akan digunakan uji Augmented Deckey Fuller Test. Data yang digunakan untuk estimasi VAR/VECM perlu dilakukan uji stasioneritasnya terlebih dahulu. Suatu data dikatakan stasioner jika nilai rata-rata dan variannya untuk berbagi lag yang berbeda nilainya adalah konstan sepanjang waktu. Untuk mendekati stasioneritas data inflasi, suku bunga SBI (rSBI), jumlah uang beredar (JUB) dan Kurs dilakukan dengan menggunakan Augmented Deckey Fuller (ADF) Test. Uji ADF yang digunakan pada tingkat level maupun pada first difference dengan series data bulanan dari tahun 2008.1 sampai dengan 2016.12.

Tabel 1. Uji Stasioneritas Data

\begin{tabular}{|l|c|l|c|l|}
\hline \multirow{2}{*}{ Variabel } & \multicolumn{2}{|c|}{ Level } & \multicolumn{2}{c|}{ Derajat 1 (D1) } \\
\cline { 2 - 5 } & Probability & Keterangan & Probability & Keterangan \\
\hline Inflasi & 0,0000 & Stasioner & 0,0000 & Stasioner \\
\hline rSBI & 0,1973 & Tidak Stasioner & 0,0000 & Stasioner \\
\hline JUB & 0,9997 & Tidak Stasioner & 0,0000 & Stasioner \\
\hline Kurs & 0,8569 & Tidak Stasioner & 0,0000 & Stasioner \\
\hline \hline
\end{tabular}

Sumber : Data Sekunder Diolah

Hasil ADF test terhadap variabel pada tingkat level menunjukkan bahwa dari empat variabel, hanya variabel inflasi yang stasioner, dan ketiga variabel (rSBI, JUB, dan Kurs) tidak stasioner. Hal ini ditunjukkan oleh nilai probabilita untuk inflasi lebih kecil dari alfa 5 persen, dimana probabilita Inf sebesar 0,0000. Dan untuk ketiga variabel yang lain memperoleh nilai probability lebih besar dari alfa 5 persen atau lebih besar dari 0,05, dimana probabilita rSBI sebesar 0,1973; JUB sebesar 0,9997; dan Kurs sebesar 0,8569. Karena tidak stasioner pada level atau 1(0) maka dilakukan uji ADF pada first difference. Berdasarkan hasil pengujian menunjukkan bahwa semua variabel pada tingkat first difference bersifat stasioner dengan alfa 5 persen, dengan demikian maka data yang telah stasioner tesebut dapat digunakan untuk analisis dengan menggunakan model VAR/VECM.

\section{Hasil Uji Lag Optimal}

Lag optimal merupakan jumlah lag yang memberikan pengaruh atau respons yang signifikan. Isu tentang penentuan panjang lag optimal semakin penting seiring dengan anggapan bahwa pemilihan lag yang tepat akan menghasilkan residual yang bersifat Gaussian, yaitu residual yang terbebas dari permasalahan autokorelasi dan heterokedastisitas. Penentuan panjang lag optimal dalam studi ini menggunakan beberapa krietria informasi antara lain: Likelihood Ratio Test (LR), Final 


\section{Elastisitas - Jurnal Ekonomi Pembangunan \\ Vol. 1 No. 1, (2019), 54 - 65}

Prediction Error (FPE), Akaike Information Criterion (AIC) dan Schwarz Criterion (SC) serta Hannan-Quinn (HQ). Hasil VAR lag order selection secara lengkap dapat dilihat pada tabel 2 .

Table 2. Hasil Pengujian Lag Optimal

\begin{tabular}{|c|c|c|c|c|c|c|}
\hline Lag & LogL & LR & FPE & AIC & sc & $H Q$ \\
\hline 0 & $-2072,711$ & NA & $8,50 \mathrm{e}+12$ & 41,12298 & $41,22655^{*}$ & 41,16491 \\
\hline 1 & $-2039,366$ & 63,38764 & $6,03 \mathrm{e}+12$ & 40,77953 & 41,29737 & 40,98917 \\
\hline 2 & $-2014,190$ & 45,86523 & $5,04 \mathrm{e}+12$ & 40,59782 & 41,52995 & 40,97517 \\
\hline 3 & $-1988,340$ & 45,04656 & $4,16 \mathrm{e}+12$ & 40,40276 & 41,74916 & 40,94782 \\
\hline 4 & $-1963,529$ & 41,26836 & $3,52 \mathrm{e}+12$ & 40,22831 & 41,98898 & $40,94108^{*}$ \\
\hline 5 & $-1945,081$ & 29,22576 & $3,39 \mathrm{e}+12$ & 40,17981 & 42,35477 & 41,06030 \\
\hline 6 & $-1919,981$ & $37,77444^{*}$ & $2,88 \mathrm{e}+12^{*}$ & $39,99961^{*}$ & 42,58884 & 41,04781 \\
\hline \multicolumn{7}{|c|}{ * indicates lag order selected by the criterion } \\
\hline \multicolumn{7}{|c|}{ LR: sequential modified LR test statistic (each test at $5 \%$ level) } \\
\hline \multicolumn{7}{|c|}{ FPE: Final prediction error } \\
\hline \multicolumn{7}{|c|}{ AIC: Akaike information criterion } \\
\hline \multicolumn{7}{|c|}{ SC: Schwarz information criterion } \\
\hline \multicolumn{7}{|c|}{ HQ: Hannan-Quinn information criterion } \\
\hline
\end{tabular}

Hasil perhitungan lag optimal dari tabel di atas menunjukkan bahwa lag optimal untuk jalur nilai tukar masingmasing kriteria memiliki nilai referensi lag optimal yang berbeda. Tiga kriteria yaitu LR dan FPE serta AIC merekomendasikan lag enam sebagai lag optimal. Sedangkan kriteria SC merekomendasikan lag nol dan kriteria HQ merekomendasikan lag empat sebagai lag yang optimal. Berdasarkan kriteria dan pertimbangan yang dijelaskan sebelumnya, maka digunakan lag 6 (enam) sebagai lag optimal.

\section{Hasil Uji Kointegrasi}

Menurut Firdaus (2011), uji kointegrasi dilakukan untuk menentkan apakah variabel-variabel yang tidak stasioner pada level terkointegrasi atau tidak. Uji kointegrasi mengimplikasikan bahwa dalam sistem persamaan tersebut terdapat error correction model yang menggambarkan adanya dinamisasi jangka pendek secara konsisten dengan hubungan jangka panjangnya. Kointegrasi mempresentasikan hubungan jangka panjang. Uji kointegrasi dalam penelitian ini menggunakan pendekatan Johansen dengan membandingkan trace statistic dengan nilai kritis sebesar 5 persen. Jika nilai trace statistic lebih besar dibandingkan dengan nilai kritisnya maka terdapat kointegrasi dalam sistem persamaan tersebut (Masyitha, 2012:51).

Tabel 3. Hasil Uji Kointegrasi Johansen

\begin{tabular}{|ccccc|}
\hline \hline $\begin{array}{c}\text { Hypothesized } \\
\text { No. of CE(s) }\end{array}$ & Eigenvalue & $\begin{array}{c}\text { Trace } \\
\text { Statistic }\end{array}$ & $\begin{array}{c}0.05 \\
\text { Critical Value }\end{array}$ & Prob.** \\
\hline \hline None * & 0,351473 & 87,25189 & 47,85613 & 0,0000 \\
At most 1 * & 0,183169 & 43,94679 & 29,79707 & 0,0006 \\
At most 2 * & 0,123522 & 23,71451 & 15,49471 & 0,0023 \\
At most 3 * & 0,099947 & 10,53020 & 3,841466 & 0,0012 \\
\hline \hline
\end{tabular}

Trace test indicates 4 cointegrating eqn(s) at the 0.05 level

* denotes rejection of the hypothesis at the 0.05 level

**MacKinnon-Haug-Michelis (1999) p-values

Sumber: Data sekunder, diolah

Hasil uji kointegrasi pada table 3 menunjukkan bahwa terdapat hubungan kointegrasi. Hal ini dikarenakan nilai trace statistic lebih besar dibaningkan dengan nilai kritisnya. Terkointegrasinya variabelvariabel pengamatan, maka langkah selanjutnya adalah pembuktian keseimbangan jangka panjang melalui uji VECM.

\section{Analisis Hasil VAR/VECM}

\section{Hasil Estimasi VAR/VECM Jangka Pendek}

Berdasarkan tabel 4 dapat dijelaskan bahwa JUB dalam jangka pendek berpengaruh positif terhadap Kurs, sedangkan rSBI dan inflasi bernilai negatif masing-masing sebesar -149.2563, dan 728.3274 .

Table 4. Hasil Estimasi VECM Jangka Pendek

\begin{tabular}{|l|l|}
\hline \hline \multicolumn{2}{|l|}{ Jalur Nilai Tukar (Kurs, rsbi, JUB, dan Inflasi) } \\
\hline \multicolumn{2}{|l|}{ Jangka Pendek } \\
\hline Peubah & Koefisien \\
\hline CointEq1 & $-1,406852$ \\
\hline D( (DrSBI -1)) & $-149,2563$ \\
\hline D(DJUB (-1)) & 0,003625 \\
\hline D(DKURS (-1)) & $-0,945237$ \\
\hline D(DINFLASI(-1)) & $-728,3274$ \\
\hline \hline
\end{tabular}

Sumber: Data Sekunder

Makna dari hasil uji VAR/VECM yang bernilai negativ yaitu variabel rSBI dan inflasi adalah mampu menahan (menguatkan) nilai tukar sebesar 149,2563; dan 728,3274 (cateris paribus). Variabel JUB bernilai positif yaitu sebesar 0,003625 persen yang bermakna variabel tersebut mampu memicu melemahnya nilai tukar sebesar 0,3 persen (cateris paribus). 
Hasil Estimasi VAR/VECM Jangka Panjang

Table 5. Hasil Estimasi Jangka Panjang

\begin{tabular}{|l|l|}
\hline \multicolumn{2}{|c|}{ Model III untuk Jalur Nilai Tukar (Kurs, rsbi, JUB, dan Inflasi) } \\
\hline \multicolumn{2}{|l|}{ Jangka Panjang } \\
\hline Peubah & Koefisien \\
\hline D(DrSBI (-1)) & $-77,58739$ \\
\hline D(DJUB (-1)) & $-0,019657$ \\
\hline D(DKURS (-1)) & 0,147673 \\
\hline D(DINFLASI(-1)) & 5244,718 \\
\hline
\end{tabular}

Dalam jangka panjang rSBI dan JUB berpengaruh negatif terhadap nilai tukar yang ditunjukkan oleh hasil dari uji VAR/VECM yaitu -77,58739 dan 0,019657. Angka-angka tersebut bermakna ketika variabel tersebut mengalami kenaikan sebesar satu satuan (cateris paribus) maka mampu menahan nilai tukar sebesar 77,58739 persen untuk rSBI; dan 0,019657 persen untuk JUB. Sedangkan inflasi berpengaruh positif terhadap nilai tukar, ditunjukkan hasil uji VAR/VECM yaitu sebesar 5244,718, yang bermakna bahwa setiap inflasi mengalami kenaikan sebesar satu satuan maka mampu memicu nilai tukar sebesar 5244,718 rupiah per 1 US dollar.

\section{Innovation Accounting}

Innovation Accounting ini mencoba untuk menguraikan bagaimana dan seberapa besar pengaruh shock atau disturbance terhadap variabel-variabel yang dibentuk dalam persamaan. Innovation Accounting terdiri dari Impulse Response Function (IRF) dan Forecast Error Variance Decomposition (FEVD). IRF berfungsi untuk melihat shock atau guncangan dari beberapa variabel terhadap inflasi selama periode pengamatan, sedangkan Variance Decomposition untuk melihat seberapa besar komposisi dari variabel tersebut dapat menjelaskaan inflasi.

\section{Hasil Uji Impulse Response Function (IRF)}

Uji IRF ini berfungsi untuk menggambarkan ekspektasi k-periode ke depan dari kesalahan prediksi suatu variabel akibat inovasi dari variabel lain dan melacak respons saat ini. Jadi, lamanya pengaruh shock suatu variabel terhadap variabel lain sampai pengaruhnya hilang atau kembali ke titik keseimbangan (Ajija dkk, 2011:168).
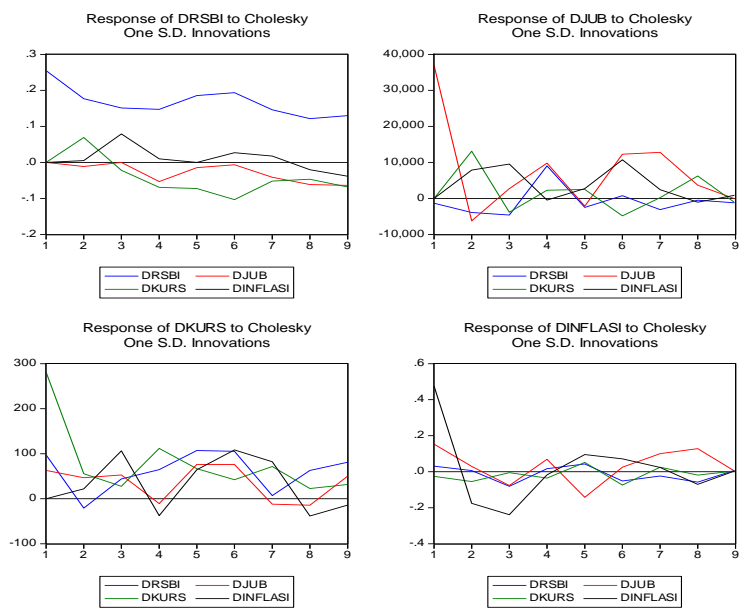

Sumber: data sekunder diolah

Impulse Response akan menunjukkan respon suatu variabel akibat kejutan variabel lainnya sampai dengan beberapa periode setelah terjadinya shock. Jika gambar Impulse Response menunjukkan pergerakan yang semakin mendekati titik keseimbangan (convergence) atau kembali ke keseimbangan sebelumnya bermakna respon suatu variabel akibat suatu kejutan makin lama akan menghilang sehingga kejutan tersebut tidak meninggalkan pengaruh permanen terhadap variabel tersebut.

Jika terjadi guncangan pada jalur nilai tukar mengalami trend yang negatif artinya adalah variabel tersebut menyebabkan terjadinya depresisai terhadap nilai tukar, sedangkan jika mengalami trend positif artinya adalah variabel tersebut menyebabkan terjadinya depresisai terhadap nilai tukar. Secara rinci hasil IRF pada masin-masing variabel menunjukkan bahwa rSBI pada awal periode hingga akhir periode menunjukkan trend yang berfluktuatif negatif (melemahkan kurs). JUB pada awal hingga akhir periode menunjukkan trend yang berfluktuatif negatif. Inflasi pada awal periode hingga periode ketujuh 
berfluktuatif negatif, masuk pada periode kedelapan hingga akhir periode menunjukkan trend positif dan stabil secara permanen.

\section{Hasil Uji Forecast Error Variance Decomposition (FEVD) atau Variance Decomposition(VD)}

FEVD atau VD digunakan memberikan informasi mengenai proporsi dari pergerakan pengaruh shock pada sebuah variabel terhadap variabel lainnya pada periode yang akan datang. Hasil uji FEVD/ VD pada jalur nilai tukar (kurs), adalah sebagai berikut.

\begin{tabular}{l} 
Tabel 6. Hasil Forecast Error Variance Decomposition (FEVD) \\
\begin{tabular}{|c|c|c|c|c|c|}
\hline Period & S.E. & DRSBI & DJUB & DKURS & DINFLASI \\
\hline 1 & 0,501184 & 0,375781 & 9,306460 & 0,270109 & 90,04765 \\
\hline 2 & 0,534713 & 0,344530 & 8,479039 & 1,290539 & 89,88589 \\
\hline 3 & 0,596223 & 2,134543 & 8,478862 & 1,045944 & 88,34065 \\
\hline 4 & 0,601725 & 2,173036 & 9,640588 & 1,368399 & 86,81798 \\
\hline 5 & 0,629130 & 2,456166 & 13,92212 & 1,921902 & 81,69981 \\
\hline 6 & 0,640061 & 3,024095 & 13,60266 & 3,189837 & 80,18341 \\
\hline 7 & 0,649195 & 3,072527 & 15,60391 & 3,246996 & 78,07656 \\
\hline 8 & 0,668252 & 3,644985 & 18,40896 & 3,145559 & 74,80049 \\
\hline 9 & 0,668353 & 3,661511 & 18,40347 & 3,149609 & 74,78541 \\
\hline
\end{tabular} \\
\hline
\end{tabular}

(a) Guncangan rSBI terhadap Inflasi Dapat dijelaskan bahwa, pada periode awal (dalam jangka pendek) guncangan (shock) terhadap inflasi diakibatkan oleh guncangan rSBI sebesar 0,38 persen, dan semakin meningkat sampai periode akhir (dalam jangka menengah), guncangan terhadap inflasi diakibatkan oleh guncangan rSBI sebesar 3,7 persen.

(b) Guncangan JUB terhadap Inflasi Dapat dijelaskan bahwa, pada periode awal (dalam jangka pendek) guncangan (shock) terhadap inflasi diakibatkan oleh guncangan JUB sebesar 9,31 persen, dan semakin meningkat sampai periode akhir (dalam jangka menengah), guncangan terhadap inflasi diakibatkan oleh guncangan JUB sebesar 18,40 persen.

(c) Guncangan Kurs terhadap Inflasi Dapat dijelaskan bahwa, pada periode awal (dalam jangka pendek) guncangan (shock) terhadap inflasi diakibatkan oleh guncangan kurs sebesar 0,27 persen, dan semakin meningkat sampai periode akhir (dalam jangka menengah), guncangan terhadap inflasi diakibatkan oleh guncangan kurs sebesar 3,15 persen.

(d) Guncangan terhadap Inflasi

Periode pertama (dalam jangka pendek) angka inflasi diakibatkan oleh guncangan yang terjadi oleh perubahan indek harga konsumen sebesar sebesar 90.05 persen dan semakin menurun pengaruhnya pada periode akhir (jangka menenah) adalah sebesar 74.78 persen. Jadi pada model konvensional, variabel inflasi (IHK) sebagai indicator inflasi (IHK) sebagian besar dipengaruhi oleh JUB sebesar 10.40 persen.

Penjelasan di atas mengindikasikan bahwa sepanjang periode, yakni dari periode 1 (selama 1 bulan) sampai dengan periode akhir (selama 9 bulan) guncangan (shock) rSBI, JUB, dan Kurs terhadap inflasi akan semakin besar. Hal ini dikarenakan inflasi (IHK) mendapatkan pengaruh langsung dari semua indikator (indikator makro) yang dijadikan sebagai instrument dalam jalur moneter, serta memiliki kontribusi adanya guncangan pada transmisi moneter.

Jalur nilai tukar berpandangan bahwa perubahan nilai tukar atau kurs merupakan variabel yang berpengaruh terhadap tercapainya sasaran akhir kebijakan moneter, khususnya perekonomian terbuka dengan sistem nilai tukar mengambang bebas. Apabila bank sentral menjalankan kebijakan moneter yang kontraktif, maka suku bunga nominal domestik akan meningkat. Jika pada saat yang sama suku bunga asing (SIBOR) tidak berubah, maka perbedaan antara suku bunga domestik dengan suku bunga luar negeri (interest rate differential) meningkat, hal ini akan medorong capital inflow. Akibatnya, nilai tukar mata uang domestik (rupiah) akan terapresiasi yang selanjutnya menyebabkan kegiatan ekspor akan menurun, dan sebaliknya kegiatan impor meningkat. Sehingga current account dalam neraca pembayaran akan membaik, akibatnya permintaan agregat 
akan menurun dan selanjutnya berpengaruh terhadap inflasi (Boediono, 1998).

Hasil studi ini berbeda dengan kondisi yang disyaratkan dalam teori purchasing power parity (PPP) bahwa gejolak nilai tukar berpengaruh terhadap variablitas harga barang-barang yang diperdagangkan (tradeable) yang selanjutnya berpengaruh terhadap variabilitas inflasi, adalah tidak relevan jika dikaitkan dengan kondisi perekonomian Indonesia dalam rentang waktu kajian ini dilakukan. Hal ini terjadi karena nilai tukar Rupiah terhadap US dolar selain dipengaruhi oleh faktor ekonomi juga dipengaruhi oleh faktor non-ekonomi misalnya faktor sentimen pasar dan gejolak politik. Di samping itu, teori PPP hanya berlaku dalam jangka panjang (Dornbusch dkk, 2004: 127) dan (MacDonald, 1989: 74) serta (Mankiw, 2003: 206).

\section{SIMPULAN DAN REKOMENDASI}

$$
\begin{aligned}
& \text { Variabel-variabel makro dalam } \\
& \text { jalur nilai tukar telah bekerja dalam } \\
& \text { mentransmisikan perubahan kebijakan } \\
& \text { moneter melalui guncangan instrumen } \\
& \text { kebijakan (rSBI, JUB, nilai tukar, dan } \\
& \text { inflasi) hingga tercapainya sasaran akhir } \\
& \text { kebijakan moneter dengan kecepatan atau } \\
& \text { time lag dan kekuatan yang berbeda antara } \\
& \text { variabel yang satu dengan variabel lainnya. } \\
& \text { Mekanisme transmisi kebijakan } \\
& \text { moneter melalui jalur nilai tukar } \\
& \text { membutuhkan time lag atau kecepatan } \\
& \text { sekitar } 6 \text { bulan hingga terwujudnya sasaran } \\
& \text { akhir kebijakan moneter (inflasi). Respons } \\
& \text { indikator makro pada jalur nilai tukar } \\
& \text { terhadap perubahan instrument moneter } \\
& \text { (suku bunga SBI) relative lemah, } \\
& \text { sedangkan variabel utama pada jalur ini } \\
& \text { yaitu nilai tukar (kurs) hanya mampu } \\
& \text { menjelaskan variasi inflasi sebesar } 3,15 \\
& \text { persen, lebih kecil dibandingkan dengan } \\
& \text { porsi yang dapat dijelaskan oleh Jumlah } \\
& \text { Uang Beredar (JUB) }
\end{aligned}
$$

Rekomendasi dari hasil temuan adalah Bank Indonesia sebagai otoritas moneter tertinggi, harus dapat mengelola dengan baik volatilitas variabel nilai tukar agar inflasi dapat dikendalikan pada tingkat yang rendah dan stabil. Karena UU No.3 Tahun 2004 tentang BI Pasal 7 Ayat (1) memberi mandat kepada BI untuk menjaga kestabilan nilai rupiah.

\section{REFERENSI}

Ascarya, Heni Hasanah, dan Noer A. Achsani. (2008). Perilaku Permintaan Uang dalam Sistem Moneter Ganda di Indonesia. Buletin Ekonomi, Moneter dan Perbankan Bank Indonesia Vol.11 No.1. Jakarta:Bank Indonesia.

Boediono. (1998). "Ekonomi Makro. Seri Sinopsis Pengantar Ilmu Ekonomi No. 2. Edisi Ketiga. Yogyakarta: Badan Penerbit Fakultas Ekonomi (BPFE) UGM.

Firduas, M. (2017). Aplikasi Ekonometrika, Untuk Data Panel dan Time Series. IPB, Press. Bogor

Maina Vincent Gitonga. Analysis of Interest Rate Channel of Monetary Transmission Mechanism in Kenya. International Journal of Business and Commerce Vol. 4, No.04 [3867] (ISSN: 2225-2436) Published by Asian Society of Business and Commerce Research 38

Warjiyo, Perry, dan Solikin. (2003). "Kebijkan Moneter di Indonesia". Jakarta: PPSK Bank Indonesia.

Warjiyo, Perry. (2004). "Mekanisme Transmisi Kebijakan Moneter Di Indonesia”. Buku Seri Kebanksentralan No.11. Jakarta: Pusat Pendidikan dan Studi Kebanksentralan (PPSK).

Adolfson, M (2001) Monetary Policy With Incomplete Exchange Rate PassThrough. Working Paper Series, No.127, Sveriges Riksbank.

Bernanke B and Blinder A (1992) The Federal Funds Rate and The Channels of Monetary Transmission. American Economic Review 82, 901-921. 


\section{Elastisitas - Jurnal Ekonomi Pembangunan \\ Vol. 1 No. 1, (2019), 54 - 65}

Bernanke B and Gertler M (1995) Inside the Black Box: The Credit Channel of Monetary Policy Transmission. Journal of Economic Perspectives 9, 27-48.

Berananke B and Mihov I (1998) Measuring Monetary Policy. The Quarterly Journal of Economics 113, 869-902.

Bhattacharya I and Ray P (2007) How Do We Assess Monetary Policy Stance? Characterisation of a Narrative Monetary Measure for India. Economic and Political weekly 42, 1201-1210.

Bhattacharya R, Patnaik I and Shah A (2011) Monetary Policy Transmission in an Emerging Market Setting. IMF Working Paper $11 / 5$.

Bhattacharya I and Sensarma R (2008) How Effective are Monetary Policy Signals in India: Evidence from a SVAR Model. Journal of Policy Modelling 30, 169-183.

Bjornland H (2005) Monetary Policy and Exchange Rate Interactions in a Small Open Economy. University of Oslo, Department of Economics. Memorandum No.31.

Coibion O (2012) Are the Effects of Monetary Policy Shocks Big or Small? American Economic Journal: Macroeconomics 4, 1-32.

Chin, L., Azali, M. and Matthews, K. G. (2007). The Monetary Approach to Exchange Rate Determination for Malaysia. Applied Economic Letters, 3: 91 - 94.

Eichenbaum M and Evans C (1995) Some Empirical Evidence on the Effects of Shocks to Monetary Policy on Exchange Rates. The Quarterly Journal of Economics 110, 9751009

Hyder, Z. and Mehboob, A. (2005). Equilibrium Real Effective Exchange Rate and Exchange Rate
Misalignment in Pakistan. SBP Conference 2005.

Hsieh, Wen-jen. (2009). Study of the Behavior of the Indonesian Rupiah/US Dollar Exchange Rate and Policy Implications. International Journal of Applied Economics, 6(2) September 2009: 41-50.

Karim, M. S., Lee, M. and Gan, C. (2007). Exchange Rate Dynamics of New Zealand. Journal of Economic Policy Reforms, 10(3):241-260

Mishkin, F.S. (2004). The Economics of Money, Banking and Financial Markets. Seventh Edition. Internasional Edition, New York: Pearson Addison Wesley Longman

Mohan R (2008) Monetary Policy Transmission in India. BIS Papers on Transmission Mechanisms for Monetary Policy in Emerging Market Economies. No.35.

Moreno, R, (2008) Monetary Policy Transmission and Long Term Interest Rate in Emerging Markets. In Transmission Mechanism for Monetary Policy in Emerging Market Economies. Working Paper No. 35,. BIS.

Sims C and Zha T (2006) Were there Regime switches in U.S. Monetary Policy? American Economic Review 96, 54-81.

Taylor J (1995) The Monetary Transmission Mechanism: An Empirical Framework. Journal of Economic Perspectives 9, 11-26.

Williamson, J. (2009). Exchange Rate Economics. Open Econ Rev, 20: 123-146.

Wilson, I. (2009). The Monetary Approach to Exchange Rates: A Brief Review and Empirical Investigation of Debt Management: Evidence from United States, The Journal of Business Inquiry, 8(1): 83-99. 